\title{
Characteristics, functions, and applications of metallothionein in aquatic vertebrates
}

\section{Wei-Chao Wang, Huan Mao, Dan-Dan Ma and Wan-Xi Yang*}

The Sperm Laboratory, College of Life Sciences, Zhejiang University, Hangzhou, China

\section{Edited by:}

Rathinam Arthur James,

Bharathidasan University, India

Reviewed by:

Xiao Huang, Zhejiang University, China

Xiaoshou Liu, Ocean University of China, China

\section{*Correspondence:}

Wan-Xi Yang, The Sperm Laboratory, College of Life Sciences, Zhejiang University, 866 Yu Hang Tang Road, Hangzhou, Zhejiang 310058, China e-mail:wxyang@spermlab.org
The documents on Metallothioneins (MTs) in aquatic creatures, especially focusing on their function as biomarkers in environmental monitoring programmes, are vast and increasing. There are, however, few papers to summary the physiological role of MTs in aquatic organisms especially on development. The multifaceted roles of MTs include involvement in homeostasis, protection against heavy metals and oxidant damages, and metabolic regulation, sequestration and/or redox control. In this paper, we have collected published information on MTs in aquatic organisms-pisces, amphibians, mammals, etc., and analyzed their function in these aquatic animals. MTs have four main functions in aquatic vertebrate. They are respectively bioaccumulation of toxic metals and detoxification, homeostatic regulation of metals, protection against oxidative stress and neuroprotective mechanism. MTs separate in different tissues and they have various distributions in different tissues of aquatic vertebrate, including liver, gills, kidney, testes, and brain. MTs can be induced by a variety of environmental and physiological factors, among which, heavy metals are the main kind of MTs inducers in aquatic vertebrate. Here we pay more attention on the essential metals copper $(\mathrm{Cu})$ and zinc $(\mathrm{Zn})$ and the non-essential metals cadmium (Cd), silver (Ag), lead (Pb), and mercury (Hg).

Keywords: heavy metals, metallothionein, homeostasis, detoxification, aquatic vertebrates

\section{INTRODUCTION}

The MTs were initially found in equine renal cortex (Margoshes and Vallee, 1957). With respect to aquatic species, in the marine fish Sebastes seboides MTs were first revealed by Olafson and Thompson (1974), who described the occurrence of low molecular weight, cadmium-binding proteins. MTs or Metallothioneinlike protein (MTLP) have since been demonstrated in many vertebrates including fish (Roeva et al., 1999).

MTs play an important role in processes of cellular protection from actions of harmful agents (metals, free radicals, etc.) and in mechanisms controlling growth, differentiation and proliferation of cells, explicating their nuclear vs. cytoplasmic localization (Dziegiel, 2004). MTs are not only cytoplasmic protein, but also accumulate in lysosomes, yet could be transported to the nucleus and to the intermembrane space of mitochondria (Tsujikawa et al., 1991; Ye et al., 2001). Notably, they are also not merely intracellular, and could be exported from cells and absorbed by other cells via a receptor-mediated mechanism, in which the protein remains in an endocytotic compartment and the metal could be transported to the cytosol (Moltedo et al., 2000; Wolff et al., 2006; Hao et al., 2007).

\section{STRUCTURE CHARACTERISTICS OF MTS}

The distinguishing trait of MTs is that one-third of their amino acids are cysteines. Templeton and Cherian (1991) found that the

Abbreviations: FHM, Fathead minnows; MeHg, Methylmercury; MTLP, Metallothionein-like protein; MTF-1, Metal regulatory transcription factor 1; MRE, metallothionein promoter region; ROS, reactive oxygen species. behavior of MTs is dependent on the chemistry of the thiol group, such that any metal sharing stoichiometric characteristics with copper or zinc, may also link to MTs. Until quite recently, the most notable characteristics of the primary structure of all MTs was the Cys-Cys, Cys-X-Cys, and Cys-X-X-Cys structural motifs, herein X stands for an amino acid residue except Cys. Furthermore, these motifs display a strong affinity to bind metal ions such as $\mathrm{Cu}, \mathrm{Zn}$, Cd, and Hg (Vallee, 1991).

Lower organisms synthesize monodominial MTs that bind monovalent mentals, whereas higher organisms have bidominial MTs that bind divalent metals. Vertebrate MTs show a bidominial structure with divalent metals as $\mathrm{Zn}(\mathrm{II})$ or $\mathrm{Cd}(\mathrm{II})$. In vertebrate MTs, the $\beta$-domain contains an M3Cys 9 cluster and the $\alpha$-domain contains an M4Cys 11 cluster, herein M stands for Zn(II) or Cd(II) (Arseniev et al., 1988; Robbins et al., 1991). Each Zn(II) ions in the clusters of MT is in a tetrathiolate coordination environment. However, seven Zn(II) ions locate in different environment, one type of zinc ions has two terminal sulfurs and two bridging sulfurs, another type of zinc ions has three bridging sulfurs (Vasák et al., 1981). The different environment leads to affinity variation over four orders of magnitude. Thus, the process of metal-binding occurs via a sequential, non-cooperative mechanism (Krezel and Maret, 2007).

\section{FUNCTIONS OF MTs}

In the past few years, MTs were suggested to act in the processes such as apoptosis, regulation of neuronal growth, and protection against free radicals and other oxidants (Vasák and Hasler, 2000). 
Gradually, the facts that MTs are involved in the homeostatic regulation of metals which provides a reservoir of metals for other metalloproteins or metalloenzymes, in heavy metal detoxification, in protection of tissues against various forms of oxidative injuries and transferring of essential metals (Coyle et al., 2002; Baird et al., 2006) (Figure 1). All the phenomena could be elucidated by chemical property of the thiolate bond (Suzuki et al., 2002). Some deep-sea fish species like Alepocephalus rostratus sequester heavy metals like $\mathrm{Hg}$ and Ag bound to MT under the synergy effects of Se (Siscar et al., 2014). Caretta caretta and Chelonia mydas also secretes mucus containing MT proteins that decrease $\mathrm{Cu}$ and $\mathrm{Cd}$ concentrations in hepatic and renal (Andreani et al., 2008). Generally, the MT expression level is dose-dependent on heavy metals. However, the response of MT to metals is not positively correlated when the amount of metals overdose (Walker et al., 2014).

In mammals the disruption of the MT-I and MT-II genes and interruption of MTs synthesis resulted in a loss of tolerance to Cd (Masters et al., 1994). Furthermore, important activities of MTs are not limited to metal ion homeostasis, but also include the enhancement of cellular survival and tissue regeneration, metabolic activity, and the blunting of pathways that promote inflammatory or apoptotic responses (Swindell, 2010). Hepatic MTs inhibit apoptosis by regulating caspase- 3 activity in Carassius auratus gibelio (Falfushynska et al., 2014). MT also protect testis and liver in the marine teleost Gobius niger from Cd effects (Migliarini et al., 2005).

Organisms with the induction of MTs could tolerate oxidation stress better, because MTs have effects of removing hydroxyl $\left(\mathrm{OH}^{*}\right)$ and super oxide $\left(\mathrm{O}^{2-}\right)$ radicals (Amiard et al., 2006). Because of a high content of cysteine, MTs can also function as an antioxidant in aquatic vertebrates (Xie and Klerks, 2004). In addition, another strong evidence is that metallothionein gene expression is regulated by oxidative stress (Glen, 1999). Thus, the synthesis of MTs could be regarded as a step of oxidative stress. Besides, MTs are involved in anti-oxidation effects. The response of MT to Tributyltin (TBT) is not positively correlated and the

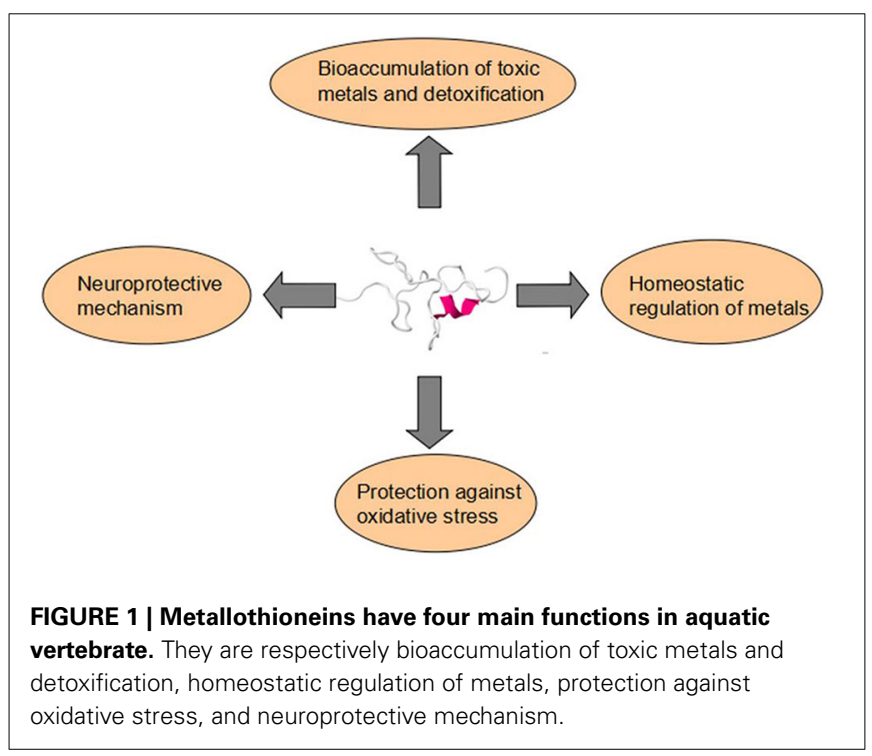

latter has led to marine pollution which induced testicular toxicity (Mitra et al., 2013).

In Channa punctata MTs are proposed to have a free-radicalscavenging activity, and their expression may be regulated in response to stress and chemical exposure (Atif et al., 2008). Besides, MTs are also involved in cytochrome induced oxidative damages in the brain, such investigation has been carried out in rainbow trout (Erdoğan et al., 2011).

\section{THE STRUCTURAL ANALYSIS OF METALLOTHIONEIN}

Hemibarbus mylodon metallothionein cDNA possesses the common features of vertebrate MTs including the high rate of Cys residues as Cys-X-Cys or Cys-Cys forms in the conserved positions. Genomic structure of $H$. mylodon metallothionein revealed the conserved characteristics of the tripartite exon/intron structure with the conserved splicing junction rule (GT/AG) (Cho et al., 2008). H. mylodon metallothionein cDNA shows three putative polyadenylation signals in the $3^{\prime}$-UTR, implying the possible processing of the mRNA species with different lengths (Cho et al., 2008). Existence of multiple polyadenylation signals in metallothionein mRNA were also found in other teleost species including common carp (Chan et al., 2004), zebrafish (Chen et al., 2004), and crucian carp (Ren et al., 2006). The 5'-flanking sequences of $H$. mylodon metallothionein shared a high degree of homology with previously known vertebrate metallothionein especially on the conserved motifs and/or the core sequences for the binding of known transcriptional factors such as TFIID, AP-1, Sp1, and HNF-5 (Haq et al., 2003; Lin et al., 2004; Ren et al., 2006). Metal response elements (MREs) play an important role in binding target for the transcription activating protein factor MRE-binding transcription factor-1 (MTF-1), controlling both basal and heavy metal-induced metallothionein transcription (Haq et al., 2003). Moreover, the transcriptional activation of H. mylodon metallothionein during metal exposures followed a dose-and/or time-dependent manner (Cho et al., 2008).

The localization of mRNAs to different compartments of the cell allows the synthesis of proteins as to where they are needed, and signals within the $3^{\prime}$ UTR have been implicated in such addressing particularly for metallothionein (Mickleburgh et al., 2004). Some studies perspicuously indicated that abnormal $3^{\prime}$ UTR modified by deletion or mutation may induce a rapid degradation of the metallothionein mRNA (Muhlrad and Parker, 1999; Levadoux-Martin et al., 2001). Some previous studies demonstrated that a tandem repeat of a CACC could be essential for the transcript localization (Chabanon et al., 2004; Nury et al., 2005).

\section{TRANSCRIPTIONAL REGULATION OF METALLOTHIONEIN}

Metal-induced regulation of metallothionein has been described in several recent reviews (Miles et al., 2000). MTF-1 is important in the regulation of a group of genes that play a key role in cellular response to various stressors (Lichtlen et al., 2001). MREs are known in multiple copies in the metallothionein promoter region, and they appear to be variable in their response to metal-induced transcription. Interestingly, $\mathrm{Zn}, \mathrm{Cd}$ and $\mathrm{Bi}$ ions could activate the promoter of the metallothionein via MREs (Palmiter, 1994).

However, there are other potential pathways of metal induction, since protein kinase $\mathrm{C}$ inhibitors have been found to inhibit 
$\mathrm{Zn}$ and Cd induction of MTs in Chinese hamster cells (Yu et al., 1997). Moreover, MREs can interact with various nuclear proteins that either activate or inhibit transcription (Tang et al., 1999; Miles et al., 2000; Ogra et al., 2001). There is evidence that several MREs could respond directly to hypoxia and oxidants, possibly via MTF-1, although these conditions may also separate $\mathrm{Zn}$ from protein ligands which could then activate MTF-1 (Murphy et al., 1999). A similar combination of inflammatory factors has been discovered to facilitate the MTs and acute phase response in mice following restraint stress (Hernández et al., 2000). Nucleotide sequences except MREs in the metallothionein promoter have been found to respond to glucocorticoids (Plisov et al., 1994; Kelly et al., 1997), interleukin-6 (IL-6) (Lee et al., 1999), phorbol esters (Angel et al., 1987), and hydrogen peroxide (Dalton et al., 1994). Reactive oxygen intermediates produced during the inflammatory response may induce MTs via multiple pathways, including directly stimulating an antioxidant response element and specific MREs in the promoter region as well as by events correlating with various seconds-messenger protein kinase pathways (Arizono et al., 1993) (Table 1).

\section{FOUND IN AQUATIC VERTEBRATE THE INDUCTION OF MTS}

MTs are also induced by other agents, such as hormones, pharmaceuticals, alcohols, cytokines, alkylating agents, irradiation, infection, reactive oxygen species, and other diverse chemical treatments (Waalkes and Goering, 1990). Nonetheless, some isoforms are relatively not sensitive to these inducers (Samson and Gedamu, 1998).

Piscator (1964) found increased metallothionein levels in the liver of rabbits exposed to $\mathrm{Cd}$. $\mathrm{Zn}$ is the most effective inducer of metallothionein transcription, while non-toxic $\mathrm{Cu}$ levels do not induce MTs, although it is often bound to MTs in vivo (Munger

\section{Table 1 | List of the published studies on regulation pathways of metallothionein transcription and expression.}

\begin{tabular}{|c|c|}
\hline Regulation pathways of metallothionein & References \\
\hline Metal-induced regulation of metallothionevia MREs & Miles et al., 2000 \\
\hline $\begin{array}{l}\text { Protein kinase } \mathrm{C} \text { inhibitors inhibit } \mathrm{Zn} \text { and } \mathrm{Cd} \\
\text { induction of MTs }\end{array}$ & Yu et al., 1997 \\
\hline $\begin{array}{l}\text { MREs interact with various nuclear proteins that } \\
\text { either activate or inhibit transcription }\end{array}$ & Miles et al., 2000 \\
\hline $\begin{array}{l}\text { MREs respond directly to hypoxia and oxidants, } \\
\text { possibly via MTF-1 }\end{array}$ & Murphy et al., 1999 \\
\hline $\begin{array}{l}\text { A similar combination of inflammatory factors } \\
\text { facilitate the MTs and acute phase response in } \\
\text { mice following restraint stress }\end{array}$ & $\begin{array}{l}\text { Hernández et al., } \\
2000\end{array}$ \\
\hline $\begin{array}{l}\text { Nucleotide sequences except MREs in the } \\
\text { metallothionein promoter respond to } \\
\text { glucocorticoids }\end{array}$ & $\begin{array}{l}\text { Plisov et al., 1994; } \\
\text { Kelly et al., } 1997\end{array}$ \\
\hline Interleukin-6 (IL-6) & Lee et al., 1999 \\
\hline Phorbol esters & Angel et al., 1987 \\
\hline Hydrogen peroxide & Dalton et al., 1994 \\
\hline $\begin{array}{l}\text { Reactive oxygen intermediates correlate with } \\
\text { various seconds-messenger protein kinase } \\
\text { pathways }\end{array}$ & Arizono et al., 1993 \\
\hline
\end{tabular}

et al., 1985). This is in contrast to the binding affinities. Therefore, the capability to induce MTs could not be reflected by the binding affinity of the metal to MTs (Zafarullah et al., 1989). Cd is another usual metal inducer of MTs, Coho salmon receiving low dose of Cd exposure result in induction of MT in liver, gill and olfactory tissues respectively and the effects can be superposed (Espinoza et al., 2012).

In addition to chemical treatments, MTs are also in response to physical treatment. Crucian carp (Carassius cuvieri) exposed to air-pumbing stress reveal time-dependent induction of MT-like metal-binding proteins (Muto et al., 1999).

\section{THE SATURATION OF DETOXIFICATION MECHANISM}

Such a saturation of expression is consistent with previous observation on the responses of MTs and other metalloenzymes during acute exposure to relatively high doses of heavy metals (De Smet et al., 2001; Yan and Chan, 2004; Cheung et al., 2005; Cho et al., 2006). It is worth noting that not only metal dose but also duration time should be taken into account (Van Campenhout et al., 2010). However, in some fish species, like the yellow perch (Perca flacescens), such threshold exposure concentration is not appreciable (Campbell et al., 2005).

\section{MT DISTRIBUTION IN DIFFERENT TISSUES OF AQUATIC VERTEBRATE}

Heavy metals accumulate in tissues of aquatic animals and hence heavy metals detected in tissues of aquatic animals can reflect the exposures (Kalay et al., 1999; Canli and Atli, 2003; Y1lmaz, 2003, 2005) (Figure 3). Much of the variation in trace metal tissue concentrations in aquatic organisms has been ascribed to the diversity in size as well as age of individuals (Farkas et al., 2003), sex (Al-Yousuf et al., 2000), and feeding habits (Canli et al., 2001; Yilmaz, 2005). Ubiquitous detection of metallothionein mRNA in various of tissues was not surprising, because many other previous findings have established the extensive tissue distribution in fish species (Chan et al., 2004; Lin et al., 2004). Tissuespecific rising of metallothionein mRNA under metal exposures might have been due to the different rates of influx/efflux of metal ions relying on tissue types, which was also associated with the compensative effects of other metal-binding proteins (e.g., superoxide dismutase) of which levels were largely different among tissues (Kock et al., 1995; Cho et al., 2005; Nam et al., 2006).

\section{HEPATOPANCREAS}

Experimental animals treated with high doses of $\mathrm{Cd}$ led to morphological and functional changes in this organ (Goering and Klaassen, 1984). High MTs amount in liver but low in muscular tissues have been observed in some fish species (Chan et al., 2004; Lin et al., 2004).

In H. mylodon, liver was more sensitive to metal ions than kidney and gill (Cho et al., 2008), and the increase of hepatic metallothionein mRNA was dose-dependent in other studies (Langston et al., 2002; Lin et al., 2004; Cho et al., 2005). Induction of hepatic MTs by Cd was time-dependent but transient. Sudden increase of metal-binding proteins or metalloenzymes in short 


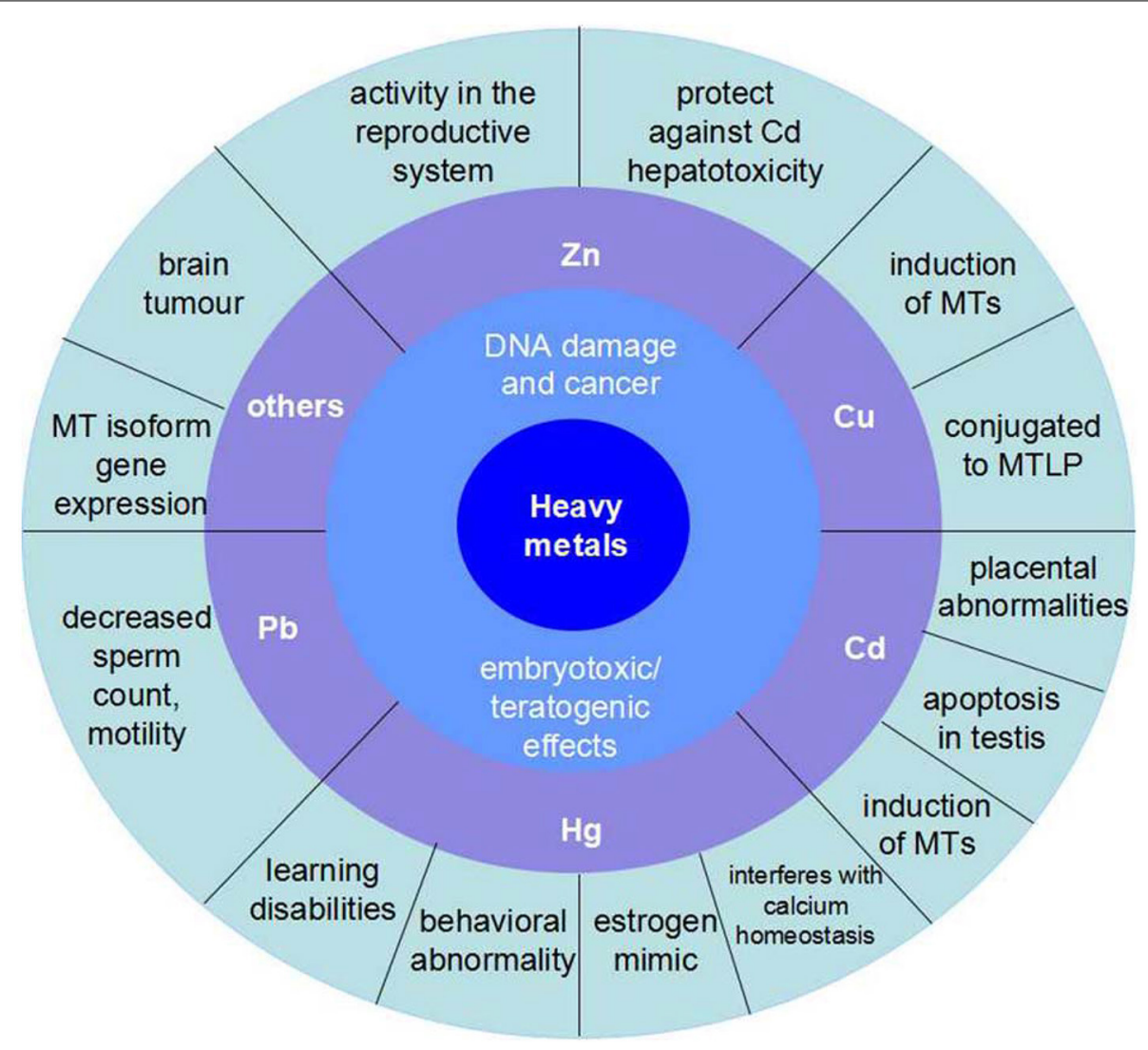

FIGURE 2 | The influence of main kinds of heavy metals on aquatic vertebrate. $\mathrm{Zn}$ has activity in the reproductive system and protects against $\mathrm{Cd}$ hepatotoxicity. $\mathrm{Cu}$ is a kind of induction of MTs and conjugated to MTLP. Cd is the course of placental abnormalities and apoptosis in testis, besides, it is also another induction of MTs. Hg mainly has damages to nervous system, which would reduce the ability of learning and result in behavioral abnormality. In addition, the organic $\mathrm{Hg}$ is a kind of estrogen mimic and interferes with calcium homeostasis. $\mathrm{Pb}$ can decreases sperm count and motility. period and then decrease down in longer exposures has been found before, and it might be due to the "indication of saturation" or "acclimation process" of the organisms to tissue loads resulted from accumulated metals (Langston et al., 2002; Basha and Rani, 2003; Cho et al., 2006).

\section{GILL}

Although gills are thought to be not only the first target organ for acute metal toxicity in fish but also the predominant absorption site of waterborne toxicants, metal accumulation, and MTs induction in fish gills have been revealed to be very species-specific, with some dispute on fish species (Boeck et al., 2003). Piscine gills comprise a diversity of cell-types such as pavement cells, chloride cells, mucous cells and respiratory cells, and the major cell type dedicated to MTs expression in response to metal exposure are chloride cells although there have been species-specific variations (Dang et al., 2001). In H. mylodon, gill showed a quite low sensitiveness to most metal exposures, despite its relatively high basal level of metallothionein mRNA (Cho et al., 2008).

\section{KIDNEY}

Along with liver, piscine kidney was an universal target to investigate metal toxicity and MTs expression, since this organ has been often reported to be one of main sites for the high accumulation of metals especially during acute phase, although the direct relationship between tissue burden (tissue metal concentration) and MTs expression has not been shown (Hollis et al., 2001; Szebedinszky et al., 2001; Cho et al., 2005). Long-term, even lowlevel, exposure to this metal also results in kidney destroy characterized by tubular dysfunction (Elinder et al., 1987). Increased nephrotoxicity of $\mathrm{Cd}$ in animals provided with $\mathrm{Zn}$-deficient diet may be a consequence of the augmented renal $\mathrm{Cd}$ deposition and reduced synthesis of MTs, noted in these conditions of exposure (Fox et al., 1984; Waalkes, 1986; Panemangalore, 1993). The action of $\mathrm{Zn}$ can contribute to a reducing amount of $\mathrm{Cd}$ bound to MTs because $\mathrm{Cd}^{2+}$ ions are bound in the kidney cytosol by $\mathrm{Zn}$ induced MTs (Squibb and Fowler, 1984; Sato and Nagai, 1989; Suzuki et al., 1990; Liu et al., 1992, 1994).

\section{TESTIS}

Some investigation indicated that testicular MTs does not act in the defense of the testes by $\mathrm{Zn}$ and that some other mechanisms must be involved (Waalkes et al., 1988; Wahba et al., 1994). In the black goby Gobius niger, it not only shows the toxic effect of Cd on hepatic tissue, but also suggests its potency as apoptotic factor in the testis (Migliarini et al., 2005). 


\section{NERVOUS TISSUE}

MT gene is also expressed in the Xenopus central nervous system. MT transcripts were found in several fractions, especially in cellular bodies of periventricular regions (Durliat et al., 1999). This pattern is very similar to most other studied vertebrates (Hao et al., 1994; Choudhuri et al., 1995). This suggests that MT may play similar functions in all vertebrate brains.

In the study on brain tissue of ringed seal, there was apparently little relationship between MT levels in brain and other tissues (Sonne et al., 2009). There are two possible courses, first, blood brain barrier may be rather impermeable for metals and subsequently resulting in low MT concentrations. Second, there is a brain-specific form of MT which is supposed not to be affected by metal stress (Uchida et al., 1991).

\section{THE INFLUENCE OF SOME HEAVY METALS ON AOUATIC VERTEBRATE}

Organisms inhabiting contaminated waters present fairly high metal concentrations. Heavy metal venting into the marine environment can impair both marine species diversity and ecosystems, owing to their toxicity and accumulative behavior (Matta et al., 1999) (Figure 2).

Heavy metals are harmful materials that would lead to DNA damage and cancer (Valko et al., 2006). A distinguished increase of DNA breaks was found in peripheral blood cells of Oreochromis niloticus exposed to water samples including

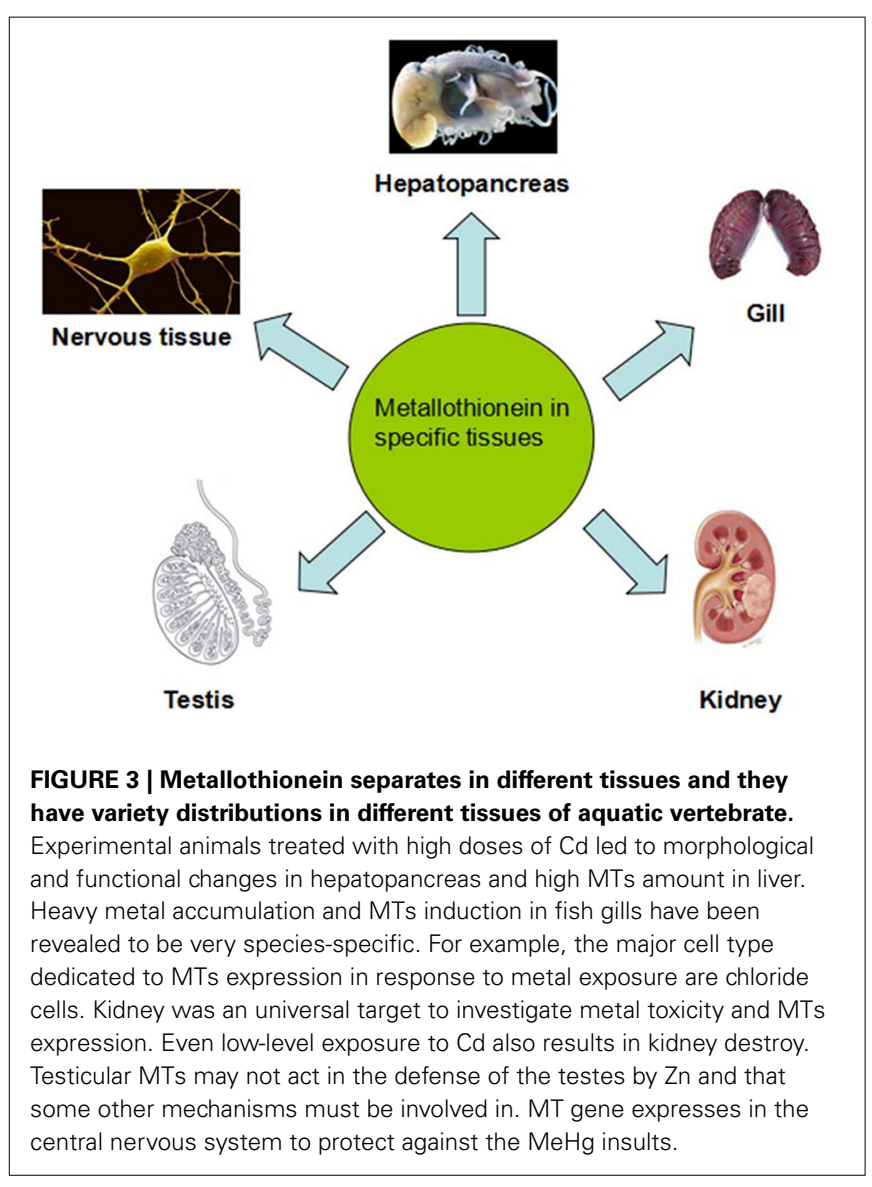

chromium (Matsumoto et al., 2006). Heavy metals such as lead, nickel, and zinc, among other metals, available in water and in the branchial, muscle, and hepatic tissues of two fish species was not followed by change in micronucleated erythrocyte frequency (Koca et al., 2008). These effects may be on account of the strong toxicity that high concentration of heavy metals may exert on fish cells (Cavas et al., 2005).

Heavy metals may cause embryotoxic/teratogenic effects via affecting cellular physiology (Calevro et al., 1998). Metal accumulation relies on tissue metabolism and differences in their chemical environment, including presence of various ligands, each with different metal-binding characteristics (Campenhout et al., 2004). Different extent of tolerance of each fish species to different heavy metals may also induce different expression level of MTs (Boeck et al., 2003; Kim et al., 2012). Notably, differential regulation of metallothionein by various metals has been revealed in many other fish species (Cho et al., 2005). Besides, the reason for metal-specific potential for MTs induction could generally been interpreted by the different availability of each metal ion in each organism or cell type (Kock et al., 1995; Olsvik et al., 2001).

In the previous study, the toxicity of metals was much more severe in younger fingerings (3-month-old) than juveniles (9-month-old) of H. mylodon, and sub-lethal doses of waterborne metals for juveniles led to remarkable mortality of younger fingerings, which was obviously proportional to the increasing doses (Cho et al., 2008).

\section{ZINC}

It was presumed that molecular mechanism of $\mathrm{Zn}$ activity in the reproductive system may be associated with metal binding MTs (Kheradmand et al., 2010). Under the non-exposed condition, MTs are known to be linked principally by $\mathrm{Zn}$, and higher accumulation of $\mathrm{Zn}$ might be required to induce additional MTs synthesis (Zhang and Wang, 2005). Zn can also prevent the pancreas from toxicity of Cd (Suzuki et al., 1990).

It has been demonstrated that pre-exposed $\mathrm{Zn}$ prior to $\mathrm{Cd}$ protects against $\mathrm{Cd}$-induced liver toxicity, including lipid peroxidation and cell damage, even utilizing lethal doses of $\mathrm{Cd}$ (Goering and Klaassen, 1984; Khan et al., 1991; Kudo et al., 1991). $\mathrm{Zn}$ induces MTs synthesis with following changes in the hepatic subcellular Cd distribution (Goering and Klaassen, 1984). A shielding action of $\mathrm{Zn}$ against $\mathrm{Cd}$ hepatotoxicity has also been exhibited in in vitro studies (Chan and Cherian, 1992).

\section{COPPER}

The induction of MTs was partially ascribed to the $\mathrm{Cu}$ regulation process (McCarter and Roch, 1984; Boeck et al., 2003), and MTs may be in favor of $\mathrm{Cu}$ storage. For instance, in black sea bream Acanthopagrus Schlegeli, it appeared that MTs concentration increased 4.1-fold in the gastrointestine, 2.0-fold in the gills, and 1.8-fold in the carcass, compared with the extent of $\mathrm{Cu}$ accumulation (4.2-fold in the gastrointestine, 2.3-fold in the gills, and 1.5-fold in the carcass, separately) in fish (Dang et al., 2009). It was well-known that excess $\mathrm{Cu}$ ions are disruptors for ion homeostasis especially in gills of fish species, which might lead to a significant adverse effect on the viability of the fish (Dang et al., 2001). It was also observed that an increase 
in hepatic $\mathrm{Cu}$ conjugated to MTLP in perch (Perca fluviatilis) exposed to $\mathrm{Cu}$ (Hogstrand and Haux, 1991; Kraemer et al., 2005). Increased levels of MT mRNA levels were also found in the zebrafish (Danio rerio) larvae and a liver cell-line under exposure to $\mathrm{Cu}_{2} \mathrm{O}$ nanoparticle and $\mathrm{CuCl}_{2}$ (Chen et al., 2011).

\section{CADMIUM}

$\mathrm{Cd}$ is one of the most toxic heavy metals and its toxicity has been widely investigated and reported. This metal is a serious environmental and occupational contaminant and may cause a severe hazard to the health of man and animals (Staessen et al., 1999). And the mortality and MTs levels were not directly related across groups exposed to different metals: the highest induction of metallothionein mRNA was achieved by $\mathrm{Cd}$ rather than $\mathrm{Cu}$ (Cho et al., 2008).

Cd appears to cause a variety of adverse reproductive effects in humans and experimental animals. Even low-level exposure to $\mathrm{Cd}$, the metal still has its accumulation in placenta, placental abnormalities, decrease in birth weight, embryonic growth retardation, and malformations (Kuhnert et al., 1987; Fréry et al., 1993; Wier et al., 1993; Milnerowicz and Zasławski, 1995; Kantola et al., 2000). In addition, Cd exposure also results in pathological conditions in liver, testis, brain, and nervous system, kidney, spleen, and bone marrow (Shen and Sangiah, 1995; Yamano et al., 1998). Cadmium exposure can also lead to apoptosis in testes of rat, mouse liver, and human T-cells (Xu et al., 1996; Habeebu et al., 1998; Tsangaris and Tzortzatou-Stathopoulou, 1998). Cadmium appears to inhibit microtubule sliding in bovine sperm axoneme (Kanous et al., 1993).

Therefore, the strong Cd-inducibility of MTs from Panulirus argus in the nervous tissue might suggest an available mechanism that would make this tissue from the lobster to treat with this highly neurotoxic contaminant. And the role of MTs in nervous tissue of vertebrates has been suggested (Kramer et al., 1996; Tallkvist et al., 2002). Cd was the most potential for MTs induction among three metals (i.e., $\mathrm{Cd}, \mathrm{Cu}$, and $\mathrm{Zn}$ ) in $H$. mylodon, and this outcome was consistent with previous discoveries that $\mathrm{Cd}$ was one of very powerful inducers for metallothionein transcription in fish (De Smet et al., 2001; Hermesz et al., 2001; Chan et al., 2006; Cho et al., 2008). It had been also suggested that transcriptional regulation of metallothionein in the fingerings of this species should be very sensitive to $\mathrm{Cd}$, and any potential harmful stress to this species origin from the Cd pollution at much lower concentration than $0.1 \mathrm{mM}$ in wild habitats may be detected by tracing the MTs expression in fingerlings if the exposure is extended (Cho et al., 2008).

\section{MERCURY}

After emission, inorganic $\mathrm{Hg}$ is methylated by microbes and enters aquatic food chains. Methylmercury $(\mathrm{MeHg})$ is the most toxic form of $\mathrm{Hg}$, and almost all (95-99\%) $\mathrm{Hg}$ in fish is $\mathrm{MeHg}$ (Grieb et al., 1990). Notably, the highest concentrations of $\mathrm{MeHg}$ are found in piscivorous fish and wildlife (Spry and Wiener, 1991).

$\mathrm{MeHg}$ is neurotoxic, particularly in developing nervous systems, and has been related to many different neurological problems, from learning disabilities and behavioral abnormality to death (Zelikoff et al., 1995). Fathead minnows (FHM), Pimephales promelas, if fed MeHg-contaminated diets, showed a delay in spawning, a decline in spawning activity, and a decline in the quantities of eggs laid along with increasing $\mathrm{MeHg}$ (Hammerschmidt et al., 2002). Besides, dietary MeHg also damages gonadal development in walleye Sander vitreus (Friedmann et al., 1996) and walking catfish Clarias batrachus (Kirubagaran and Joy, 1988, 1992) and leads to testicular atrophy in guppies (Wester, 1991). And there is some evidence suggesting that MeHg inhibits sex hormones that cause secondary sex characteristics and stimulate gonadal development and gametogenesis. Specifically, MeHg could interfere with vitellogenesis (Kirubagaran and Joy, 1988) and spermatogenesis (Kirubagaran and Joy, 1992). In another study, it was found that MeHg exposure decreased phospholipid content in ovarian tissue of fish and implied that this may contribute to inhibition of vitellogenin synthesis in the liver (Kirubagaran and Joy, 1995). In previous studies, exposure to environmentally related concentrations of $\mathrm{MeHg}$ suppressed gonadal development and estrogen production in female FHM and testosterone in male FHM (Drevnick and Sandheinrich, 2003). Therefore, MeHg may function as an endocrine disruptor by binding to estrogen receptors and acting virtually as an estrogen mimic (Klaper et al., 2006). In addition, $\mathrm{MeHg}$ appears to affect bone cells, inducing hypercalcemia in goldfish and interferes with calcium homeostasis (Suzuki et al., 2004).

\section{LEAD}

Lead $(\mathrm{Pb})$ is extensive used chemical for the preparation of large industry and household-based products. The toxicity of lead compounds, like all other heavy metals, was related to different disorders in humans (Saxena et al., 1986). More importantly, it has been recently noticed that lead compounds could result in oxidative stress in various tissues along with the generation of reactive oxygen species (ROS) (Quinlan et al., 1988; Acharya and Acharya, 1997; Hsu et al., 1998). In general, ROS are involved in impairing the polyunsaturated fatty acids of the membrane phospholipids of the cells causing defects of cellular functions (Halliwell and Gutteridge, 1985). Pb exposure was also related with tissue oxidative damage in chicks (Donaldson and Leeming, 1984) and rats (Sandhir et al., 1994).

$\mathrm{Pb}$-treatment has been known to associate with decreased sperm count, motility, and increased morphological abnormalities in animals (McGivern et al., 1991; Sokol and Berman, 1991) and humans (Lerda, 1992; Alexander et al., 1996). A report demonstrated that $\mathrm{Pb}$ exposure stimulated ROS generation in rat spermatozoa, which was negatively correlated with fertility (Hsu et al., 1997). Pb exposure might descend defense ability of sperm to the oxidative stress and enhance the ROS generation, reduce sperm motility and oocyte penetration capability in rat (Hsu et al., 1998). More evidences have revealed that testicular physiologies, basically characterized by spermatogenesis process, could be at least partially controlled by reactive oxygen-dependent mechanisms (Koizumi and Li, 1992). It is well-known that ROS could cause chromosomal aberrations by mutating certain gene segments, resulting in abnormal sperm population and/or dramatically reduce in sperm count (Eyden et al., 1978; Hartwing 
et al., 1990; Koizumi et al., 1992; Hsu et al., 1998). For instance, chromosomal aberrations, increased sperm abnormalities and decreased sperm count profile in lead-exposed mice (Usha et al., 2003).

\section{OTHER HEAVY METALS AND ARSENIC (AR)}

Tin-protoporphyrin regulates heme oxygenase and metallothionein gene expression through heme-hemopexin interaction, since tin-protoporphyrin is a kind of heme analog (Piotrowski and Szymańska, 1976). After 7 days of exposure to nickel chloride, MT accumulation in sexually immature sea bass Dicentrarchus labrax increased with a marked synergetic effect (Banni et al., 2011). The study of rainbow trout presented that cobalt exposure result in increased expression levels of metallothionein genes. Since the organism like fishes do not have ability to completely discharge or decompose heavy metals, they tend to bio-accumulate the non-eliminated metals rather than decompose or discharge heavy metals, which may lead to fish death at last. Bismuth is known to induce the synthesis of renal metallothionein (Disilvestro et al., 1996).

Fisrt, inducation of Ar was found in rat hepatic metallothionein in vivo (Albores et al., 1992). Complex interactions also were found between Ar and human metallothionein (Toyama et al., 2002; Ngu and Stillman, 2006). Recently, influence of As on MT isoform gene expression in Human Glioblastoma cells was clearly demonstrated, As may be related with brain tumor and type II cell death (Falnoga et al., 2012).

\section{THE CONTRIBUTION OF MTS TO AQUATIC ANIMAL ESPECIALLY ON DEVELOPMENT}

MTs appear to play a predominant role in the metabolism and detoxification of Cd in marine organisms (George et al., 1996). During oxidative stress, synthesis of MTs may increase several times (Thornalley and Vasak, 1985) to prevent the cells from cytotoxicity (Aschner et al., 1998) and DNA damage (Cai et al., 1995).

In another study, basal level of $H$. mylodon metallothionein mRNA reached highest in ovary, indicating that the rich metallothionein mRNAs in ovary would be transported to early embryos (Cho et al., 2008). The transmitted metallothionein mRNAs may act a critical role in the fine regulation of metal homeostasis which is one of primary requirements for normal embryogenesis and early larval development (Chen et al., 2004).

\section{APPLICATION OF MTS AS A BIOMARKER FOR EVALUATING THE AQUATIC ENVIRONMENT}

Owing to its highly inducible expression during exposures to various heavy metals, MTs have been paid much attention as a potential biomarker to monitor the heavy metal pollution of aquatic ecosystem, a major receptor of pollutants especially with relatively high amount of heavy metals (Langston et al., 2002; Tom et al., 2004; Cho et al., 2005). Nevertheless, the application of MTs to biomarker assay needs large evaluation of a number of abiotic and biotic factors such as salinity, $\mathrm{pH}$, temperature, seasonality, fish age, sex, and reproductive cycle that may affect the expression of MTs (Chen et al., 2004; Marijić and Raspor, 2006).

\section{CONCLUSIONS}

We reviewed the recent advances of characteristics, functions and applications of metallothionein in aquatic vertebrates, the general function of MT, transcription regulation, induction factors, and the influence on the development of aquatic vertebrates were summarized. MTs could be induced by various physiological and toxicological stimuli, such as oxidative stress (suggesting that in vivo they may inactivate hydroxyl radicals), cytokines, chemicals, and heat as well as heavy metals. Sensitive regulation of the MTs expression by heavy metal exposures would make it possible to use the transcriptional quantification of the present MTs as a biomarker for evaluating metal pollutions. We then focus on the role of MTs in different organs and tissues. Marine heavy metal pollution is increasingly serious, which leads to oxidative stress, cell apoptosis, and neuron damage in marine vertebrates and human who eat seafood. MTs can protect aquatic vertebrates from harmful metals especially during development. More importantly, the study indicates a novel way to protect human from polluted sea products.

\section{ACKNOWLEDGMENTS}

We are indebted to all members of the Sperm Laboratory at Zhejiang University for their enlightening discussion. This work was supported in part by the National Natural Science Foundation of China (No. 41276151).

\section{REFERENCES}

Acharya, S., and Acharya, U. R. (1997). In vivo lipid peroxidation responses of tissues in lead-treated Swiss mice. Ind. Health. 35, 542-544. doi: 10.2486/indhealth.35.542

Albores, A., Koropatnick, J., Cherian, M. G., Zelazowski, A. J., and Acharya, U. R. (1992). Arsenic induces and enhances rat hepatic metallothionein production in vivo. Chem. Biol. Interact. 85, 127-140. doi: 10.1016/0009-2797(92)90057-R

Alexander, B. H., Checkoway, H., van Netten, C., Muller, C. H., Ewers, T. G., Kaufman, J. D., et al. (1996). Semen quality of men employed at a lead smelter. Occup. Environ. Med. 53, 411-416. doi: 10.1136/oem.53.6.411

Al-Yousuf, M. H., El-Shahawi, M. S., and Al-Ghais, S. M. (2000). Trace metals in liver, skin and muscle of Lethrinus lentjan fish species in relation to body length and sex. Sci. Total Environ. 256, 87-94. doi: 10.1016/S0048-9697(99)00363-0

Amiard, J. C., Amiard-Triquet, C., Barka, S., Pellerin, J., and Rainbow, P. S. (2006). Metallothioneins in aquatic invertebrates: their role in metal detoxication and their use as biomarkers. Aquat. Toxicol. 76, 160-202. doi: 10.1016/j.aquatox.2005.08.015

Andreani, G., Santoro, M., Cottignoli, S., Fabbri, M., Carpenè, E., and Isani, G. (2008). Metal distribution and metallothionein in loggerhead (Caretta caretta) and green (Chelonia mydas) sea turtles. Sci. Total Environ. 390, 287-294 doi: 10.1016/j.scitotenv.2007.09.014

Angel, P., Imagawa, M., Chiu, R., Stein, B., Imbra, R. J., Rahmsdorf, H. J., et al. (1987). Phorbol ester-inducible genes contain a common cis element recognized by a TPA-modulated trans-acting factor. Cell 49, 729-739. doi: 10.1016/00928674(87)90611-8

Arizono, K., Peterson, K. L., and Brady, F. O. (1993). Inhibitors of $\mathrm{Ca}^{2+}$ channels, calmodulin and protein kinases prevent A23187 and other inductions of metallothionein mRNA in $\mathrm{EC}_{3}$ rat hepatoma cells. Life Sci. 53, 1031-1037. doi: 10.1016/0024-3205(93)90126-N

Arseniev, A., Schultze, P., Wörgötter, E., Braun, W., Wagner, G., Vasák, M., et al. (1988). Three-dimensional structure of rabbit liver [Cd7]metallothionein-2a in aqueous solution determined by nuclear magnetic resonance. J. Mol. Biol. 201, 637-657. doi: 10.1016/0022-2836(88)90644-4

Aschner, M., Conklin, D. R., Yao, C. P., Allen, J. W., and Tan, K. H. (1998). Induction of astrocyte metallothioneins (MTs) by zinc confers resistance against the acute cytotoxic effects of methylmercury on cell swelling, $\mathrm{Na}^{+}$uptake, and $\mathrm{K}^{+}$release. Brain Res. 813, 254-261. doi: 10.1016/S0006-8993(98)00947-0 
Atif, F., Kaur, M., Ansari, R. A., and Raisuddin, S. (2008). Channa punctata brain metallothionein is a potent scavenger of superoxide radicals and prevents hydroxyl radical-induced in vitro DNA Damage. J. Biochem. Mol. Toxicol. 22, 202-208. doi: 10.1002/jbt.20230

Baird, S. K., Kurz, T., and Brunk, U. T. (2006). Metallothionein protects against oxidative stress-induced lysosomal destabilization. Biochem. J. 394, 275-283. doi: 10.1042/BJ20051143

Banni, M., Jebali, J., Guerbej, H., Dondero, F., Boussetta, H., and Viarengo, A. (2011). Mixture toxicity assessment of nickel and chlorpyrifos in the sea bass Dicentrarchus labrax. Arch. Environ. Contam. Toxicol. 60, 124-131. doi: 10.1007/s00244-010-9529-y

Basha, P. S., and amd Rani, A. U. (2003). Cadmium-induced antioxidant defense mechanism in freshwater teleost Oreochromis mossambicus (Tilapia). Ecotoxicol. Environ. Saf. 56, 218-221. doi: 10.1016/S0147-6513(03)00028-9

Boeck, G. D., Ngo, T. T. H., Campenhout, K. V., and Blust, R. (2003). Differential metallothionein induction patterns in three freshwater fish during sublethal copper exposure. Aquat. Toxicol. 65, 413-424. doi: 10.1016/S0166445X(03)00178-4

Cai, L., Koropatnick, J., and Cherian, M. G. (1995). Metallothionein protects DNA from copper-induced but not iron-induced cleavage in vitro. Chem. Biol. Interact. 96, 143-155. doi: 10.1016/0009-2797(94)03585-V

Calevro, F., Campani, S., Ragghianti, M., Bucci, S., and Mancino, G. (1998). Test of toxicity and teratogenicity in biphasic vertebrates treated with heavy metals $\left(\mathrm{Cr}^{3+}, \mathrm{Al}^{3+}, \mathrm{Cd}^{2+}\right)$. Chemosphere 37, 3011-3017. doi: 10.1016/S00456535(98)00342-7

Campbell, P. G., Giguère, A., Bonneris, E., Hare, L., and Metals in the Environment Research Network. (2005). Cadmium-handling strategies in two chronically exposed indigenous freshwater organisms-the yellow perch (Perca flavescens) and the floater mollusc (Pyganodon grandis). Aquat. Toxicol. 72, 83-97. doi: 10.1016/j.aquatox.2004.11.023

Campenhout, K. V., Infante, H. G., Adams, F., and Blust, R. (2004). Induction and binding of $\mathrm{Cd}, \mathrm{Cu}$, and $\mathrm{Zn}$ to metallothionein in carp (Cyprinus carpio) using HPLC-ICP-TOFMS. Toxicol. Sci. 80, 276-287. doi: 10.1093/toxsci/ kfh149

Canli, M., and Atli, G. (2003). The relationships between heavy metal (Cd, Cr, Cu, $\mathrm{Fe}, \mathrm{Pb}, \mathrm{Zn}$ ) levels and the size of six Mediterranean fish species. Environ. Pollut. 121, 129-136. doi: 10.1016/S0269-7491(02)00194-X

Canli, M., Kalay, M., and Ay, O. (2001). Metal (Cd, Pb, Cu, Zn, Fe, Cr, Ni) concentrations in tissues of a fish Sardina pilchardus and Prawn peaenus japonicus from three stations on the Mediterranean Sea. Bull. Environ. Contam. Toxicol. 67, 75-82. doi: 10.1007/s001280093

Cavas, T., Garanko, N. N., and Arkhipchuk, V. V. (2005). Induction of micronuclei and binuclei in blood, gill and liver cells of fishes subchronically exposed to cadmium chloride and copper sulphate. Food Chem. Toxicol. 43, 569-574. doi: 10.1016/j.fct.2004.12.014

Chabanon, H., Nury, D., Mickleburgh, I., Burtle, B., and Hesketh, J. (2004). Characterization of the cis-acting element directing perinuclear localization of the metallothionein-1 mRNA. Biochem. Soc. Trans. 32, 702-704. doi: 10.1042/BST0320702

Chan, H. M., and Cherian, M. G. (1992). Protective roles of metallothionein and glutathione in hepatotoxicity of cadmium. Toxicology 72, 281-290. doi: 10.1016/0300-483X(92)90179-I

Chan, K. M., Ku, L. L., Chan, P. C., and Cheuk, W. K. (2006). Metallothionein gene expression in zebrafish embryo-larvae and ZFL cell-line exposed to heavy metal ions. Mar. Environ. Res. 62, S83-S87. doi: 10.1016/j.marenvres.2006.04.012

Chan, P. C., Shiu, C. K. M., Wong, F. W. Y., Wong, J. K. Y., Lam, K. L., and Chan, K. M. (2004). Common carp metallothionein-1 gene: cDNA cloning, gene structure and expression studies. Biochim. Biophys. Acta. 1676, 162-171. doi: 10.1016/j.bbaexp.2003.11.009

Chen, D., Zhang, D., Yu, J. C., and Chan, K. M. (2011). Effects of $\mathrm{Cu}_{2} \mathrm{O}$ nanoparticle and $\mathrm{CuCl}_{2}$ on zebrafish larvae and a liver cell-line. Aquat. Toxicol. 105, 344-354. doi: 10.1016/j.aquatox.2011.07.005

Chen, W. Y., John, J. A. C., Lin, C.-H., Lin, H.-F., Wu, S.-C., Lin, C.-H., et al. (2004). Expression of metallothionein gene during embryonic and early larval development in zebrafish. Aquat. Toxicol. 69, 215-227. doi: 10.1016/j.aquatox.2004.05.004

Cheung, L. A. P., Lam, V. K. L., and Chan, K. M. (2005). Tilapia metallothionein genes: PCR-cloning and gene expression studies. Biochim. Biophys. Acta 1731, 191-201. doi: 10.1016/j.bbaexp.2005.09.006
Cho, Y. S., Choi, B. N., Ha, E. M., Kim, K. H., Kim, S. K., Kim, D. S., et al. (2005). Shark (Scyliorhinus torazame) metallothionein: cDNA cloning, genomic sequence, and expression analysis. Mar. Biotechnol. 7, 350-362. doi: 10.1007/s10126-004-0043-y

Cho, Y. S., Choi, B. N., Kim, K. H., Kim, S. K., Kim, D. S., Bang, I. C., et al. (2006). Differential expression of $\mathrm{Cu} / \mathrm{Zn}$ superoxide dismutase mRNA during exposures to heavy metals in rockbream (Oplegnathus fasciatus). Aquaculture 253, 667-679. doi: 10.1016/j.aquaculture.2005.05.047

Cho, Y. S., Lee, S. Y., Kim, K. Y., Bang, I. C., Kim, D. S., and Nam, Y. K. (2008). Gene structure and expression of metallothionein during metal exposures in Hemibarbus mylodon. Ecotoxicol. Environ. Saf. 71, 125-137. doi: 10.1016/j.ecoenv.2007.08.005

Choudhuri, S., Kramer, K. K., Berman, N. E., Dalton, T. P., Andrews, G. K., and Klaassen, C. D. (1995). Constitutive expression of metallothionein genes in mouse brain. Toxicol. Appl. Pharmacol. 131, 144-154. doi: 10.1006/taap.1995. 1056

Coyle, P., Philcox, J. C., Carey, L. C., and Rofe, A. M. (2002). Metallothionein: the multipurpose protein. Cell Mol. Life Sci. 59, 627-647. doi: 10.1007/s00018-0028454-2

Dalton, T., Palmiter, R. D., and Andrews, G. K. (1994). Transcriptional induction of the mouse metallothionein-I dene in hydrogen peroxide-treated Hepa cells involves a composite major late transcription factor/antioxidant response element and metal response promoter elements. Nucleic Acids Res. 22, 5016-5023. doi: $10.1093 /$ nar/22.23.5016

Dang, F., Zhong, H., and Wang, W.-X. (2009). Copper uptake kinetics and regulation in a marine fish after waterborne copper acclimation. Aquat. Toxicol. 94, 238-244. doi: 10.1016/j.aquatox.2009.07.011

Dang, Z., Berntssen, M. H. G., Lundebye, A. K., Flik, G., Wendelaar Bonga, S. E., and Lock, R. A. C. (2001). Metallothionein and cortiso receptors expression in gills of Atlantic salmon, Salmo salar, exposed to dietary cadmium. Aquat. Toxicol. 53, 91-101. doi: 10.1016/S0166-445X(00)00168-5

De Smet, H., De Wachter, B., Lobinski, R., and Blust, R. (2001). Dynamics of $(\mathrm{Cd}, \mathrm{Zn})$-metallothioneins in gills, liver and kidney of common carp Cyprinus carpio during cadmium exposure. Aquat. Toxicol. 52, 269-281. doi: 10.1016/S0166-445X(00)00136-3

Disilvestro, R. A., Liu, J., and Klaassen, C. D. (1996). Transgenic mice overexpressing metallothionein are not resistant to adriamycin cardiotoxicity. Res. Commun. Mol. Pathol. Pharmacol. 93, 163-170.

Donaldson, W. E., and Leeming, T. K. (1984). Dietary lead: effects on hepatic fatty acid composition in chicks. Toxicol. Appl. Pharmacol. 73, 119-123. doi: 10.1016/0041-008X(84)90060-7

Drevnick, P. E., and Sandheinrich, M. B. (2003). Effects of dietary methylmercury on reproductive endocrinology of fathead minnows. Environ. Sci. Technol. 37, 4390-4396. doi: 10.1021/es034252m

Durliat, M., Muller, J. P., André, M., and Wegnez, M. (1999). Expression of the Xenopus laevis metallothionein gene during ontogeny. Int. J. Dev. Biol. 43, 575-578.

Dziegiel, P. (2004). Expression of metallothioneins in tumor cells. Pol. J. Pathol. $55,3-12$.

Elinder, C. G., Nordberg, M., Palm, B., Bjork, L., and Jonsson, L. (1987). Cadmium, zinc, and copper in rabbit kidney metallothionein-relation to kidney toxicity. Environ. Res. 42, 553-562. doi: 10.1016/S0013-9351(87) 80222-0

Erdoğan, O., Ceyhun, S. B., Ekinci, D., and Aksakal, E. (2011). Impact of deltamethrin exposure on mRNA expression levels of metallothionein A, B and cytochrome $\mathrm{P} 4501 \mathrm{~A}$ in rainbow trout muscles. Gene. 484, 13-17. doi: 10.1016/j.gene.2011.05.026

Espinoza, H. M., Williams, C. R., and Gallagher, E. P. (2012). Effect of cadmium on glutathione S-transferase and metallothionein gene expression in coho salmon liver, gill and olfactory tissues. Aquat. Toxicol. 110-111, 37-44. doi: 10.1016/j.aquatox.2011.12.012

Eyden, B. P., Maisin, J. R., and Mattelin, G. (1978). Long-term effects of dietary lead acetate on survival, body weight and semen cytology in mice. Bull. Environ. Contam. Toxicol. 19, 266-272. doi: 10.1007/BF01685797

Falfushynska, H., Gnatyshyna, L., Turta, O., Stoliar, O., Mitina, N., Zaichenko, A., et al. (2014). Responses of hepatic metallothioneins and apoptotic activity in Carassius auratus gibelio witness a release of cobalt and zinc from waterborne nanoscale composites. Comp. Biochem. Physiol. C Toxicol. Pharmacol. 160, 66-74. doi: 10.1016/j.cbpc.2013.11.009 
Falnoga, I., Zelenik Pevec, A., Slejkovec, Z., Znidariè M. T., Zajc, I., Mlakar, S. J., et al. (2012). Arsenic Trioxide (ATO) influences the gene expression of metallothioneins in human glioblastoma cells. Biol. Trace Elem. Res. 149, 331-339. doi: 10.1007/s12011-012-9431-8

Farkas, A., Salanki, J., and Specziar, A. (2003). Age and size-specific patterns of heavy metals in the organs of freshwater fish Abramis brama L. populating a low-contaminated site. Water Res. 37, 959-964. doi: 10.1016/S0043-1354(02) 00447-5

Fox, M. R., Tao, S. H., Stone, C. L., and Fry, B. E. Jr. (1984). Effects of zinc, iron and copper deficiencies on cadmium in tissues of Japanese quail. Environ. Health Perspect 54, 57-65.

Fréry, N., Nessmann, C., Girard, F., Lafond, J., Moreau, T., Blot, P., et al. (1993). Environmental exposure to cadmium and human birth weight. Toxicology 79, 109-118. doi: 10.1016/0300-483X(93)90124-B

Friedmann, A. S., Watzin, M. C., Brinck-Johnsen, T., and Leiter, J. C. (1996). Low levels of dietary methylmercury inhibit growth and gonadal development in juvenile walleye (Stizostedion vitreum). Aquat. Toxicol. 35, 265-278. doi: 10.1016/0166-445X(96)00796-5

George, S. G., Hodgson, P. A., Tytler, P., and Todd, K. (1996). Inducibility of metallothionein mRNA expression and cadmium tolerance in larvae of a marine teleost, the turbot (Scophthalmus maximus). Fundam. Appl. Toxicol. 33, 91-99. doi: 10.1006/faat.1996.0146

Glen, K. A. (1999). Regulation of metallothionein gene expression by oxidativestress and metal ions. Biochem. Pharmacol. 59, 95-104.

Goering, P. L., and Klaassen, C. D. (1984). Zinc-induced tolerance to cadmium hepatotoxicity. Toxicol. Appl. Pharmacol. 74, 299-307. doi: 10.1016/0041008X(84)90282-5

Grieb, T. M., Driscoll, C. T., Gloss, S. P., Schofield, C. L., Bowie, G. L., and Porcella, D. B. (1990). Factors affecting mercury accumulation in fish in the upper Michigan peninsula. Environ. Toxicol. Chem. 9, 919-930. doi: 10.1002/ etc. 5620090710

Habeebu, S. S., Liu, J., and Klaassen, C. D. (1998). Cadmium-induced apoptosis in mouse liver. Toxicol. Appl. Pharmacol. 149, 203-209. doi: 10.1006/taap.1997.8334

Halliwell, B., and Gutteridge, J. M. C. (1985). The importance of free radicals and catalytic metal ions in human diseases. Mol. Aspects Med. 8, 89-93. doi: 10.1016/0098-2997(85)90001-9

Hammerschmidt, C. R., Sandheinrich, M. B., Wiener, J. G., and Rada, R. G. (2002). Effects of dietary methylmercury on reproduction of fathead minnows. Environ. Sci. Technol. 36, 877-883. doi: 10.1021/es011120p

Hao, Q., Hong, S. H., and Maret, W. (2007). Lipid raft-dependent endocytosis of metallothionein in HepG2 cells. J. Cell. Physiol. 210, 428-435. doi: $10.1002 /$ jcp. 20874

Hao, R., Cerutis, D. R., Blaxall, H. S., Rodrigue-Sierra, J. F., Pfeiffer, R. F., and Ebadi, M. (1994). Distribution of zinc metallothionein-I mRNA in rat brain using in situ hybridization. Neurochem. Res. 19, 761-767. doi: 10.1007/BF00967717

Haq, F., Mahoney, M., and Koropatnick, J. (2003). Signaling events for metallothionein induction. Mutat. Res. 533, 211-226. doi: 10.1016/j.mrfmmm.2003. 07.014

Hartwing, A., Schlepegrell, R., and Beyersmann, D. (1990). Indirect mechanism of lead-induced genetoxicity in cultured mammalian cells. Mutat. Res. 241, 75-82. doi: 10.1016/0165-1218(90)90110-N

Hermesz, E., Abraham, M., and Nemcsok, J. (2001). Tissue-specific expression of two metallothionein genes in common carp during cadmium exposure and temperature shock. Comp. Biochem. Physiol. C 128, 457-465. doi: 10.1016/S1532-0456(01)00165-X

Hernández, J., Carrasco, J., Belloso, E., Giralt, M., Bluethmann, H., Lee, D. K., et al. (2000). Metallothionein induction by restraint stress: role of glucocorticoids and IL-6. Cytokine 12, 791-796. doi: 10.1006/cyto.1999.0629

Hogstrand, C., and Haux, C. (1991). Binding and detoxification of heavy metals in lower vertebrates with reference to metallothionein. Comp. Biochem. Physiol. C 100, 137-141. doi: 10.1016/0742-8413(91)90140-O

Hollis, L., Hogstrand, C., and Wood, C. M. (2001). Tissue-specific cadmium accumulation, metallothionein induction, and tissue zinc and copper levels during chronic sublethal cadmium exposure in juvenile rainbow trout. Arch. Environ. Contam. Toxicol. 41, 468-474. doi: 10.1007/s002440010273

Hsu, P. C., Liu, M. Y., Chen, L. Y., and Guo, Y. L. (1998). Effects of vitamin E and/or $\mathrm{C}$ on reactive oxygen species-related lead toxicity in rat sperm. Toxicology 128, 169-179. doi: 10.1016/S0300-483X(98)00068-7
Hsu, P.-C., Liu, M.-Y., Hsu, C.-C., Chen, L.-Y., and Guo, Y.-L. (1997). Lead exposure causes generation of reactive oxygen species and functional impairment in rat sperm. Toxicology 122, 133-143. doi: 10.1016/S0300-483X(97)00090-5

Kalay, M., Ay, Ö., and Canli, M. (1999). Heavy metal concentrations in fish tissues from the Northeast Mediterranean Sea. Bull. Environ. Contam. Toxicol. 63, 673-681. doi: 10.1007/s001289901033

Kanous, K. S., Casey, C., and Lindemann, C. B. (1993). Inhibition of microtubule sliding by nickel and cadmium: evidence for a differential response of certain microtubule pairs within the bovine sperm axoneme. Cell Motil. Cytoskel. 26, 66-76. doi: 10.1002/cm.970260107

Kantola, M., Purkunen, R., Kroger, P., Tooming, A., Juravskaja, J., Pasanen, M., et al. (2000). Accumulation of cadmium, zinc, and copper in maternal blood and developmental placental tissue: differences between Finland, Estonia, and St. Petersburg. Environ. Res. 83, 54-66. doi: 10.1006/enrs.1999.4043

Kelly, E. J., Sandgren, E. P., Brinster, R. L., and Palmiter, R. D. (1997). A pair of adjacent glucocorticoid response elements regulate expression of two mouse metallothionein genes. Proc. Natl. Acad. Sci. U.S.A. 94, 10045-10050. doi: 10.1073/pnas.94.19.10045

Khan, S., Khan, M. A., Bhatnagar, D., Yadau, P., and Sarkar, S. (1991). Zinc protection against lipid peroxidation from cadmium. Indian J. Exp. Biol. 29, $823-825$.

Kheradmand, F., Nourmohammadi, I., Modarressi, M. H., Firoozrai, M., and Ahmadi-Faghih, M. A. (2010). Differential gene expression of metallothionein $1 \mathrm{M}$ and $1 \mathrm{G}$ in response to zinc in sertoli TM4 cells. Iran. Biomed. J. 14, 9-15.

Kim, J. H., Rhee, J. S., Dahms, H. U., Lee, Y. M., Han, K. N., and Lee, J. S. (2012). The yellow catfish, Pelteobagrus fulvidraco (Siluriformes) metallothionein cDNA: molecular cloning and transcript expression level in response to exposure to the heavy metals $\mathrm{Cd}, \mathrm{Cu}$, and $\mathrm{Zn}$. Fish Physiol. Biochem. 38, 1331-1342. doi: 10.1007/s10695-012-9621-5

Kirubagaran, R., and Joy, K. P. (1988). Toxic effects of mercuric chloride methylmercuric chloride, and Emisan 6 (an organic mercurial fungicide) on ovarian recrudescence in the catfish Clarias batrachus (L.). Bull. Environ. Contam. Toxicol. 41, 902-909. doi: 10.1007/BF02021053

Kirubagaran, R., and Joy, K. P. (1992). Toxic effects of mercury on testicular activity in the freshwater teleost, Clarias batrachus (L.). J. Fish Biol. 41, 305-315. doi: 10.1111/j.1095-8649.1992.tb02659.x

Kirubagaran, R., and Joy, K. P. (1995). Changes in lipid profiles and 32P uptake into phosphoprotein (vitellogenin) content of the ovary and liver in the female catfish, Clarias batrachus, exposed to mercury. Biomed. Environ. Sci. 8, 35-44.

Klaper, R., Rees, C. B., Drevnick, P., Weber, D., Sandheinrich, M., and Carvan, M. J. (2006). Gene expression changes related to endocrine function and decline in reproduction in fathead minnow (Pimephales promelas) after dietary methylmercury exposure. Environ. Health Perspect. 114, 1337-1343. doi: 10.1289/ehp.8786

Koca, S., Koca, Y. B., Yildiz, S., and Gurcu, B. (2008). Genotoxic and histopathological effects of water pollution on two fish species, Barbus capito pectoralis and Chondrostoma nasus in the Buyuk Menderes River, Turkey. Biol. Trace Elem. Res. 122, 276-291. doi: 10.1007/s12011-007-8078-3

Kock, G., Hoper, R., and Wograth, S. (1995). Accumulation of trace metals Cd, $\mathrm{Pb}, \mathrm{Cu}, \mathrm{Zn}$ in arctic char Salvelinus alpinus from oligotrophic alpine lakes: relation to alkalinity. Can. J. Fish Aquat. Sci. 52, 2367-2376. doi: 10.1139/ f95-829

Koizumi, T., and Li, Z. G. (1992). Role of oxidative stress in single dose, cadmium-induced testicular cancer. J. Toxicol. Environ. Health 37, 25-36. doi: $10.1080 / 15287399209531654$

Koizumi, T., Li, Z. G., and Tatsumoto, H. (1992). DNA damaging activity of cadmium in leydig cells, a target cell population for cadmium. Toxicol. Lett. 63, 211-220. doi: 10.1016/0378-4274(92)90013-A

Kraemer, L. D., Campbell, P. G. C., and Hare, L. (2005). Dynamics of Cd, Cu and $\mathrm{Zn}$ accumulation in organs and sub-cellular fractions in field transplanted juvenile yellow perch (Perca flavescens). Environ. Pollut. 138, 324-337. doi: 10.1016/j.envpol.2005.03.006

Kramer, K. K., Liu, J., Choudhuri, S., and Klaassen, C. D. (1996). Induction of metallothionein mRNA and protein in murine astrocyte cultures. Toxicol. Appl. Pharmacol. 136, 94-100. doi: 10.1006/taap.1996.0011

Krezel, A., and Maret, W. (2007). Dual nanomolar and picomolar Zn(II) binding properties of metallothionein. J. Am. Chem. Soc. 129, 10911-10921. doi: $10.1021 / \mathrm{ja} 071979 \mathrm{~s}$ 
Kudo, N., Nakagawa, Y., Waku, K., Kawashima, Y., and Kozuka, H. (1991). Prevention by zinc of cadmium inhibition of stearoyl-CoA desaturse in rat liver. Toxicology 68, 133-142. doi: 10.1016/0300-483X(91)90016-T

Kuhnert, B. R., Kuhnert, P. M., Debanne, S., and Williams, T. G. (1987). The relationship between cadmium, zinc and birth weight in pregnant women who smoke. Am. J. Obstet. Gynecol. 157, 1247-1251. doi: 10.1016/S00029378(87)80303-4

Langston, W. J., Chesman, B. S., Burt, G. R., Pope, N. D., and McEvoy, J. (2002). Metallothionein in liver of eels Anguilla anguilla from the Thames Estuary: an indicator of environmental quality? Mar. Environ. Res. 53, 263-293. doi: 10.1016/S0141-1136(01)00113-1

Lee, D. K., Carrasco, J., Hidalgo, J., and Andrews, G. K. (1999). Identification of a signal transducer and activator of transcription (STAT) binding site in the mouse metallothionein-I promoter involved in interleukin-6-induced gene expression. Biochem. J. 337, 59-65. doi: 10.1042/0264-6021:3370059

Lerda, D. (1992). Study of sperm characteristics in persons occupationally exposed to lead. Am. J. Ind. Med. 22, 567-571. doi: 10.1002/ajim.4700220411

Levadoux-Martin, M., Hesketh, J. E., Beattie, J. H., and Wallace, H. M. (2001). Influence of metallothionein-1 localization on its function. Biochem. J. 355, 473-479. doi: 10.1042/0264-6021:3550473

Lichtlen, P., Wang, Y., Belser, T., Georgiev, O., Certa, U., and Sack, R. (2001). Target gene search for the metal-responsive transcription factor MTF-1. Nucleic Acids Res. 29, 1514-1523. doi: 10.1093/nar/29.7.1514

Lin, C. H., John, J. A. C., Ou, L. W., Chen, J. C., Lin, C. H., and Chang, C. Y. (2004). Cloning and characterization of metallothionein gene in ayu Plecoglossus altivelis. Aquat. Toxicol. 66, 111-124. doi: 10.1016/j.aquatox.2003.06.003

Liu, X., Jin, T., Nordberg, G. F., Sjostrom, M., and Zhou, Y. (1994). Influence of zinc and copper administration on metal disposition in rats with cadmiummetallothionein-induced nephrotoxicity. Toxicol. Appl. Pharmacol. 126, 84-90. doi: 10.1006/taap.1994.1093

Liu, X. Y., Jin, T. Y., Nordberg, G. F., Rannar, S., Sjostrom, M., and Zhou, Y. (1992). A multivariate study of protective effects of $\mathrm{Zn}$ and $\mathrm{Cu}$ against nephrotoxicity induced by cadmium metallothionein in rats. Toxicol. Appl. Pharmacol. 114, 239-245. doi: 10.1016/0041-008X(92)90074-3

Margoshes, M., and Vallee, B. L. (1957). A cadmium protein from equine kidney cortex. J. Am. Chem. Soc. 79, 4813-4814. doi: 10.1021/ja01574a064

Marijić, V. F., and Raspor, B. (2006). Age- and tissue-dependent metallothionein and cytosolic metal distribution in a native Mediterranean fish, Mullus barbatus, from the Eastern Adriatic Sea. Comp. Biochem. Physiol. C Toxicol. Pharmacol. 143, 382-387. doi: 10.1016/j.cbpc.2005.05.019

Masters, B. A., Kelly, E. J., Qualife, C. J., Brinster, R. L., and Palmiter, R. D. (1994). Targeted disruption of metallothionein I and II genes increaeses sensitivity to cadmium. Proc. Natl. Acad. Sci. U.S.A. 91, 584-588. doi: 10.1073/pnas.91.2.584

Matsumoto, S. T., Mantovani, M. S., Malaguttii, M. I. A., Dias, A. U., Fonseca, I. C., and Marin-Morales, M. A. (2006). Genotoxicity and mutagenicity of water contaminated with tannery effluents, as evaluated by the micronucleus test and comet assay using the fish Oreochromis niloticus and chromosome aberrations in onion root-tips. Genet. Mol. Biol. 29, 148-158. doi: 10.1590/S141547572006000100028

Matta, J., Milad, M., Manger, R., and Tosteson, T. (1999). Heavy metals, lipid peroxidation, and cigateratoxicity in the liver of the Caribben barracuda (Sphyraena barracuda). Biol. Trace Elem. Res. 70, 69-79. doi: 10.1007/BF02783850

McCarter, J. A., and Roch, M. (1984). Chronic exposure of coho salmon to sublethal concentrations of Cu. III. Kinetics of metabolism of metallothionein. Comp. Biochem. Physiol. C 77, 83-87.

McGivern, R. F., Sokol, R. Z., and Berman, N. G. (1991). Prenatal lead exposure in the rat during the third week of gestation: long-term behavioral, physiological, and anatomical effects associated with reproduction. Toxicol. Appl. Pharmacol. 110, 206-215. doi: 10.1016/S0041-008X(05)80003-1

Mickleburgh, I., Burtle, B., Nury, D., Chabanon, H., Chrzanowska-Lightowlers, Z., and Hesketh, J. E. (2004). Isolation and identification of a protein binding to the localization element of metallothionein-1 mRNA. Biochem. Soc. Trans. 32, 705-706. doi: 10.1042/BST0320705

Migliarini, B., Campisi, A. M., Maradonna, F., Truzzi, C., Annibaldi, A., Scarponi, G., et al. (2005). Effects of cadmium exposure on testis apoptosis in the marine teleost Gobius niger. Gen. Comp. Endocrinol. 142, 241-247. doi: 10.1016/j.ygcen.2004.12.012

Miles, A. T., Hawksworth, G. M., Beattie, J. H., and Rodilla, V. (2000). Induction, regulation, degradation and biological significance of mammalian metallothionein. Crit. Rev. Biochem. Mol. Biol. 35, 35-70. doi: 10.1080/1040 9230091169168

Milnerowicz, H., and Zasławski, R. (1995). Effect of smoking on metals and metallothionein content in first trimester pregnant women. Diagnostyka Laboratoryjna 31, 61-67.

Mitra, S., Gera, R., Siddiqui, W. A., and Khandelwal, S. (2013). Tributyltin chloride induced testicular toxicity by JNK and p38 activation, redox imbalance and cell death in Sertoli-germ cell co-culture. Toxicology 310, 39-52. doi: 10.1016/j.tox.2013.05.011

Moltedo, O., Verde, C., Capasso, A., Parisi, E., Remondelli, P., Bonatti, S., et al. (2000). Zinc transport and metallothionein secretion in the intestinal human cell line caco-2. J. Biol. Chem. 275, 31819-31825. doi: 10.1074/jbc.M002907200

Muhlrad, D., and Parker, R. (1999). Aberrant mRNAs with extended 3' UTRs are substrates for rapid degradation by mRNA surveillance. RNA 5, 1299-1307. doi: $10.1017 /$ S1355838299990829

Munger, K., Germann, U. A., Beltramini, M., Niedermann, D., Baitella-Eberle, G., Kagi, J. H., et al. (1985). (Cu, Zn)-metallothioneins from fetal bovine liver, chemical and spectroscopic properties. J. Biol. Chem. 260, 10032-10038.

Murphy, B. J., Andrews, G. K., Bittel, D., Discher, D. J., McCue, J., Green, C. J., et al. (1999). Activation of metallothionein gene expression by hypoxia involves metal responsive elements and metal transcription factor-1. Cancer Res. 59, 1315-1322.

Muto, N., Ren, H. W., Hwang, G. S., Tominaga, S., Itoh, N., and Tanaka, K. (1999). Induction of two major isoforms of metallothionein in crucian carp (Carassius cuvieri) by air-pumping stress, dexamethasone, and metals. Comp. Biochem. Physiol. C Pharmacol. Toxicol. Endocrinol. 122, 75-82. doi: 10.1016/S07428413(98)10081-6

Nam, Y. K., Cho, Y. S., Kim, K.-Y., Bang, I. C., Kim, K. H., Kim, S. K., et al. (2006). Characterization of copper, zinc superoxide dismutase from a cartilaginous shark species, Scyliorhinus torazame (Carcharhiniformes). Fish Physiol. Biochem. 32, 305-315. doi: 10.1007/s10695-006-9107-4

Ngu, T. T., and Stillman, M. J. (2006). Arsenic binding to human metallothionein. J. Am. Chem. Soc. 128, 12473-12483. doi: 10.1021/ja062914c

Nury, D., Chabanon, H., Levadoux-Martin, M., and Hesketh, J. (2005). An eleven nucleotide section of the 3'-untranslated region is required for perinuclear localization of rat metallothionein-1 mRNA. Biochem. J. 387, 419-428. doi: 10.1042/BJ20040630

Ogra, Y., Suzuki, K., Gong, P., Otsuka, F., and Koizumi, S. (2001). Negative regulatory role of $\mathrm{Sp} 1$ in metal responsive element-mediated transcriptional activation. J. Biol. Chem. 276, 16534-16539. doi: 10.1074/jbc.M100570200

Olafson, R. W., and Thompson, J. A. J. (1974). Isolation of heavy metal binding proteins from marine vertebrates. Mar. Biol. 28, 83-86. doi: 10.1007/BF00 396298

Olsvik, P. A., Gundersen, P., Andersen, R. A., and Zachariassen, K. E. (2001). Metal accumulation and metallothionein in brown trout, Salmo trutta, from two Norwegian rivers differently contaminated with $\mathrm{Cd}, \mathrm{Cu}$ and $\mathrm{Zn}$. Comp. Biochem. Physiol. C 128, 189-201. doi: 10.1016/S1532-0456(00)00191-5

Palmiter, R. D. (1994). Regulation of metallothionein genes by heavy metals appears to be mediated by a zinc-sensitive inhibitor that interacts with a constitutively active transcription factor, MTF-1. Proc. Natl. Acad. Sci. U.S.A. 91, 1219-1223. doi: 10.1073/pnas.91.4.1219

Panemangalore, M. (1993). Interaction among zinc, copper, and cadmium in rats: effect of low zinc and copper diets and oral cadmium exposure. J. Trace Elem. Exp. Med. 6, 125-139.

Piotrowski, J. K., and Szymańska, J. A. (1976). Influence of certain metals on the level of metallothionein-like proteins in the liver and kidneys of rats. J. Toxicol. Environ. Health. 1, 991-1002. doi: 10.1080/15287397609529402

Piscator, M. (1964). On cadmium in normal human kidneys with report on the isolation of metallothionein from cadmium-exposed rabbit livers. Nord. Hyg. Tidskr. 45, 76-82.

Plisov, S. I., Merkulova, T. I., and Shkapenko, A. L. (1994). Detection of a short segment of DNA, responsible for glucocorticoid regulation, in the 5'-flanking region on the murine metallothionein I gene. Mol. Biol. (Mosk.) 28, 407-412.

Quinlan, G. J., Halliwell, B., Moorehous, C. P., and Gutteridge, J. M. C. (1988). Action of lead (II) and aluminium (III) ions in iron-stimulated lipid peroxidation in liposomes, erythrocytes and rat liver microsomal fractions. Biochem. Biophys. Acta. 962, 196-200. doi: 10.1016/0005-2760(88)90159-2

Ren, H., Xu, M., He, P., Muto, N., Itoh, N., Tanaka, K., et al. (2006). Cloning of crucian carp (Carrassius cuvieri) metallothionein-II gene and characterization 
of its gene promoter region. Biochem. Biophys. Res. Commun. 342, 1297-1304. doi: 10.1016/j.bbrc.2006.02.082

Robbins, A. H., McRee, D. E., Williamson, M., Collett, S. A., Xuong, N. H., Furey, W. F., et al. (1991). Refined crystal structure of Cd, Zn metallothionein at $2.0 \mathrm{~A}$ resolution. J. Mol. Biol. 221, 1269-1293.

Roeva, N. N., Sidorov, A. V., and Yurovitskii, Y. G. (1999). Metallothioneins, proteins binding heavy metals in fish. Biol. Bull. 26, 617-622.

Samson, S. L., and Gedamu, L. (1998). Molecular analyses of metallothionein gene regulation. Prog. Nucleic Acid Res. Mol. Biol. 59, 257-288. doi: 10.1016/S00796603(08)61034-X

Sandhir, R., Julka, D., and Gill, K. D. (1994). Lipoperoxidative damage on lead exposure in rat brain and its implications on membrane bound enzymes. Pharmacol. Toxicol. 74, 66-71. doi: 10.1111/j.1600-0773.1994. tb01077.x

Sato, M., and Nagai, Y. (1989). Effect of zinc deficiency on the accumulation of metallothionein and cadmium in the rat liver and kidney. Arch. Environ. Contam. Toxicol. 18, 587-593. doi: 10.1007/BF01055026

Saxena, D. K., Hussain, T., Lal, B., and Chandra, S. V. (1986). Lend induced testicular dysfunction in weaned rats. Ind. Health 22, 105-109. doi: 10.2486/indhealth.24.105

Shen, Y. M., and Sangiah, S. (1995). $\mathrm{Na}^{+}, \mathrm{K}^{+}$, ATPase, glutathione and hydroxyl free radicals in cadmium chloride induced testicular toxicity in mice. Arch. Environ. Contam. Toxicol. 29, 174-179. doi: 10.1007/BF00212967

Siscar, R., Koenig, S., Torreblanca, A., and Solé, M. (2014). The role of metallothionein and selenium in metal detoxification in the liver of deep-sea fish from the NW Mediterranean Sea. Sci. Total Environ. 466-467, 898-905. doi: 10.1016/j.scitotenv.2013.07.081

Sokol, R. Z., and Berman, N. (1991). The effect of age of exposure on lead-induced testicular toxicity. Toxicology 69, 269-278. doi: 10.1016/0300-483X(91)90186-5

Sonne, C., Aspholm, O., Dietz, R., Andersen, S., Berntssen, M. H., and Hylland, K. (2009). A study of metal concentrations and metallothionein binding capacity in liver, kidney and brain tissues of three Arctic seal species. Sci. Total Environ. 407, 6166-6172. doi: 10.1016/j.scitotenv.2009.08.029

Spry, D. J., and Wiener, J. G. (1991). Metal bioavailability and toxicity to fish in lowalkalinity lakes: a critical review. Environ. Pollut. 71, 243-304. doi: 10.1016/02697491(91)90034-T

Squibb, K. S., and Fowler, B. A. (1984). Intracellular metabolism and effects of circulating cadmium-metallothionein in the kidney. Environ. Health Perspect. 54, 31-35. doi: 10.1289/ehp.845431

Staessen, J. A., Roels, H. A., Emelianov, D., Kuznetsova, T., Thijs, L., Vangronsveld, J., et al. (1999). Environmental exposure to cadmium, forearm bone density, and risk of fractures: prospective population study. Lancet 353, 1140-1144. doi: 10.1016/S0140-6736(98)09356-8

Suzuki, C. A., Ohta, H., Albores, A., Koropatnick, J., and Cherian, M. G. (1990). Induction of metallothionein synthesis by zinc in cadmium pretreated rats. Toxicology 63, 273-284. doi: 10.1016/0300-483X(90)90190-R

Suzuki, K. T., Someya, A., Komada, Y., and Ogra, Y. (2002). Roles of metallothionein in copper homeostasis: responses to $\mathrm{Cu}$-deficient diets in mice. J. Inorg. Biochem. 88, 173-182. doi: 10.1016/S0162-0134(01)00376-2

Suzuki, N., Yamamoto, M., Watanabe, K., Kambegawa, A., and Hattori, A. (2004). Both mercury and cadmium directly influence calcium homeostasis resulting from the suppression of scale bone cells: the scale is a good model for the evaluation of heavy metals in bone metabolism. J. Bone Miner. Metab. 22, 439-446. doi: 10.1007/s00774-004-0505-3

Swindell, W. R. (2010). Metallothionein and the biology of aging. Ageing Res. Rev. 10, 132-145. doi: 10.1016/j.arr.2010.09.007

Szebedinszky, C., McGeer, J. C., McDonald, D. G., and Wood, C. M. (2001). Effects of chronic Cd exposure via the diet or water on internal organspecific distribution and subsequent gill Cd uptake kinetics in juvenile rainbow trout (Oncorhynchus mykiss). Environ. Toxicol. Chem. 20, 597-607. doi: 10.1002/etc. 5620200320

Tallkvist, J., Persson, E., Henriksson, J., and Tjälve, H. (2002). Cadmiummetallothionein interactions in the olfactory pathways of rats and pikes. Toxicol. Sci. 67, 108-113. doi: 10.1093/toxsci/67.1.108

Tang, C. M., Westling, J., and Seto, E. (1999). trans repression of the human metallothionein IIA gene promoter by PZ120, a novel 120-kilodalton zinc finger protein. Mol. Cell. Biol. 19, 680-689.

Templeton, D. M., and Cherian, M. G. (1991). Toxicological significance of metallothionein. Meth. Enzymol. 205, 11-24. doi: 10.1016/0076-6879(91)05079-B
Thornalley, P. J., and Vasak, M. (1985). Possible role for metallothionein in protection against radiation-induced oxidative stress. Kinetics and mechanism of its reaction with superoxide and hydroxyl radicals. Biochim. Biophys. Acta 827, 36-44. doi: 10.1016/0167-4838(85)90098-6

Tom, M., Chen, N., Segev, M., Herut, B., and Rinkevich, B. (2004). Quantifying fish metallothionein transcript by real time PCR for its utilization as an environmental biomarker. Mar. Pollut. Bull. 48, 705-710. doi: 10.1016/j.marpolbul.2003.10.013

Toyama, M., Yamashita, M., Hirayama, N., and Murooka, Y. (2002). Interactions of arsenic with human metallothionein-2. J. Biochem. 132, 217-221. doi: 10.1093/oxfordjournals.jbchem.a003213

Tsangaris, G. T., and Tzortzatou-Stathopoulou, F. (1998). Cadmium induces apoptosis differentially on immune system cell lines. Toxicology 128, 143-150. doi: 10.1016/S0300-483X(98)00032-8

Tsujikawa, K., Imai, K., Kakutani, M., Kayamori, Y., Mimura, T., Otaki, N., et al. (1991). Localization of metallothionein in nuclei of growing primary cultured adult rat hepatocytes. FEBS Lett. 283, 239-242. doi: 10.1016/00145793(91)80597-V

Uchida, Y., Takio, K., Titani, K., Ihara, Y., and Tomonaga, M. (1991). The growth inhibitory factor that is deficient in the Alzheimer's disease brain is a 68 amino acid metallothionein-like protein. Neuron 407, 6166-6172.

Usha, R. A., Rathore, R. M., and Mishra, M. (2003). Role of vitamin C on lead acetate induced spermatogenesis in swiss Mice. Environ. Toxicol. Pharmacol. 13, 9-14. doi: 10.1016/S1382-6689(02)00107-2

Valko, M., Rhodes, C. J., Moncol, J., Izakovic, M., and Mazur, M. (2006). Free radicals, metals and antioxidants in oxidative stress-induced cancer. Chem. Biol. Interact. 160, 1-40. doi: 10.1016/j.cbi.2005.12.009

Vallee, B. L. (1991). Introduction to metallothionein. Methods Enzymol. 205, 3-7. doi: 10.1016/0076-6879(91)05077-9

Van Campenhout, K., Infante, H. G., Hoff, P. T., Moens, L., Goemans, G., Belpaire, C., et al. (2010). Cytosolic distribution of $\mathrm{Cd}, \mathrm{Cu}$ and $\mathrm{Zn}$, and metallothionein levels in relation to physiological changes in gibel carp (Carassius auratus gibelio) from metal-impacted habitats. Ecotoxicol. Environ. Saf. 73, 296-305. doi: 10.1016/j.ecoenv.2009.10.007

Vasák, M., and Hasler, D. W. (2000). Metallothioneins: new functional and structural insights. Curr. Opin. Chem. Biol. 4, 177-183. doi: 10.1016/S13675931(00)00082-X

Vasák, M., Kägi, J. H., Hill, H. A. (1981). Zinc(II), cadmium(II), and mercury(II) thiolate transitions in metallothionein. Biochemistry 20, 2852-2856. doi: 10.1016/S1367-5931(00)00082-X

Waalkes, M. P. (1986). Effect of dietary zinc deficiency on the accumulation of cadmium and metallothionein in selected tissues of the rat. J. Toxicol. Environ. Health 18, 301-313. doi: 10.1080/15287398609530870

Waalkes, M. P., and Goering, P. L. (1990). Metallothionein and other cadmiumbinding proteins: recent developments. Chem. Res. Toxicol. 3, 281-288. doi: 10.1021/tx00016a001

Waalkes, M. P., Perantoni, A., Bhave, M. R., and Rehm, S. (1988). Strain dependence in mice of resistance and susceptibility to the testicular effects of cadmium: assessment of the role of testicular cadmium-binding proteins. Toxicol. Appl. Pharmacol. 93, 47-61. doi: 10.1016/0041-008X(88)90024-5

Wahba, Z. Z., Miller, M. S., and Waalkes, M. P. (1994). Absence of changes in metallothionein RNA in rat testes made refractory to cadmium toxicity by zinc pretreatment. Hum. Exp. Toxicol. 13, 65-67. doi: 10.1177/0960327194013 00110

Walker, C. J., Gelsleichter, J., Adams, D. H., and Manire, C. A. (2014). Evaluation of the use of metallothionein as a biomarker for detecting physiological responses to mercury exposure in the bonnethead, Sphyrna tiburo. Fish Physiol. Biochem. doi: 10.1007/s10695-014-9930-y. [Epub ahead of print].

Wester, P. W. (1991). Histopathological effects of environmental pollutants $3-\mathrm{HCH}$ and methylmercury on reproductive organs in freshwater fish. Comp. Biochem. Physiol. C 100, 237-239. doi: 10.1016/0742-8413(91) 90160-U

Wier, P. J., Miller, R. K., Maulik, D., and DiSant'Agnese, P. A. (1993). Toxicity of cadmium in the perfused human placenta. Toxicol. Appl. Pharmacol. 105, 156-171.

Wolff, N. A., Abouhamed, M., Verroust, P. J., Thévenod, F., and Pharmacol,. J. (2006). Megalin-dependent internalization of cadmium-metallothionein and cytotoxicity in cultured renal proximal tubule cells. J. Pharmacol. Exp. Ther. 318, 782-791. doi: 10.1124/jpet.106.102574 
Xie, L., and Klerks, P. L. (2004). Metallothionein-like protein in the least killifish Heterandria formosa and its role in cadmium resistance Environ. Toxicol. Chem. 23, 173-177. doi: 10.1897/02-652

Xu, C., Johnson, J. E., Singh, P. K., Jones, M. M., Yan, H., and Carter, C. E. (1996). In vivo studies of cadmium-induced apoptosis in testicular tissue of the rat and its modulation by a chelating agent. Toxicology 107, 1-8. doi: 10.1016/0300-483X (95)03195-L

Yamano, T., Shimizu, M., and Noda, T. (1998). Comparative effects of repeated administration of cadmium on kidney, spleen, thymus, and bone marrow in 2, 4 and 8 month old male Wistar rats. Toxicol. Sci. 46, 393-402. doi: 10.1093/ toxsci/46.2.393

Yan, C. H. M., and Chan, K. M. (2004). Cloning of zebrafish metallothionein gene and characterization of its gene promoter region in HepG2 cell line. Biochim. Biophys. Acta 1679, 47-58. doi: 10.1016/j.bbaexp.2004.04.004

Ye, B., Maret, W., and Vallee, B. L. (2001). Zinc metallothionein imported into liver mitochondria modulates respiration. Proc. Natl. Acad. Sci. U.S.A. 98, 2317-2322. doi: 10.1073/pnas.041619198

Yilmaz, A. B. (2003). Levels of heavy metals (Fe, $\mathrm{Cu}, \mathrm{Ni}, \mathrm{Cr}, \mathrm{Pb}$ and $\mathrm{Zn}$ ) in tissue of Mugil cephalus and Trachurus mediterraneus from İskenderun Bay, Turkey. Environ. Res. 92, 277-281. doi: 10.1016/S0013-9351(02) 00082-8

Yilmaz, A. B. (2005). Comparison of heavy metal levels of grey mullet (Mugil cephalus L.) and Sea Bream (Sparus aurata L.) caught in İskenderun Bay (Turkey). Turk. J. Vet. Anim. Sci. 29, 257-262.

Yu, C. W., Chen, J. H., and Lin, L. Y. (1997). Metal-induced metallothionein gene expression can be activated by protein kinase C inhibitor. FEBS Lett. 420, 69-73. doi: 10.1016/S0014-5793(97)01489-0
Zafarullah, M., Olsson, P. E., and Gedamu, L. (1989). Rainbow trout metallothionein gene structure and regulation. Oxf. Surv. Eukaryot. Genes 6, 11-143.

Zelikoff, J. T., Bertin, J. E., Burbacher, T. M., Hunter, E. S., Miller, R. K., Silbergeld, E. K., et al. (1995). Health risks associated with prenatal metal exposure. Fundam. Appl. Toxicol. 25, 161-170. doi: 10.1006/faat.1995.1052

Zhang, L., and Wang, W. X. (2005). Effects of Zn pre-exposure on Cd and Zn bioaccumulation and metallothionein levels in two species of marine fish. Aquat. Toxicol. 73, 353-369. doi: 10.1016/j.aquatox.2005.04.001

Conflict of Interest Statement: The Review Editor Xiao Huang declares that, despite being affiliated to the same institution as the authors, the review process was handled objectively and no conflict of interest exists. The authors declare that the research was conducted in the absence of any commercial or financial relationships that could be construed as a potential conflict of interest.

Received: 30 April 2014; accepted: 25 July 2014; published online: 28 August 2014. Citation: Wang W-C, Mao H, Ma D-D and Yang W-X (2014) Characteristics, functions, and applications of metallothionein in aquatic vertebrates. Front. Mar. Sci. 1:34. doi: 10.3389/fmars.2014.00034

This article was submitted to Marine Pollution, a section of the journal Frontiers in Marine Science.

Copyright (c) 2014 Wang, Mao, Ma and Yang. This is an open-access article distributed under the terms of the Creative Commons Attribution License (CC BY). The use, distribution or reproduction in other forums is permitted, provided the original author(s) or licensor are credited and that the original publication in this journal is cited, in accordance with accepted academic practice. No use, distribution or reproduction is permitted which does not comply with these terms. 